\title{
СЕРОЛОГІЧНИЙ МОНТТОРИНГ ПОШИРЕННЯ ТОКСОПЛАЗМОЗУ ДОМАШНІХ ВСЕЇДНИХ ТВАРИН У МІСТІ ОДЕСА
}

\author{
В. Кустуров
}

Одеський державний аграрний університет

У статті наведені результати моніторингу поширення токсоплазмозу серед домашніх всеїних тварин (собаки та коти) з 2014 по 2019 рр. Встановлено, що з 761 досліджених проб сироваток крові домашніх тварин у 21,7 \% наявні антитіла до Toхорlasma gondii. Виявлено сезонну закономірність зростання серопозитивних тварин влітку та зниження їх кількості восени. Відсотковий вміст серопозитивних котів та собак у видовій структурі захворювання майже однаковий та становить - 52,7\% та 47,3\% відповідно.

Ключові слова: токсоплазмоз, коти, собаки, серологічний моніторинг, антитіла, Toxoplasma gondii.

Постановка проблеми. Токсоплазмоз - одне 3 найпоширеніших паразитарних захворювань, спричинене внутрішньоклітинними найпростішими Toxoplasma gondii. Це захворювання вражає всіх теплокровних тварин. Широке поширення в світі інфекція набула серед домашніх м'ясоїдних тварин [7].Так наприклад, в країнах Европи, Південої Америки та США від 9 до 46\% кішок мали позитивні результати на токсоплазмоз, в Азії до 9\%. Кількість серопозитивних собак коливалась в межах від 18,5\% до 59\% в Нідерландах, Великобританії та США [2]. За останіми дослідженнями українських науковців, інфікованість собак в Київській області складає 49,2\%, а котів 66,7\% [4]. Інфікованість котів в місті Київ сягає 75,03\% [5].

Значну небезпеку несе токсоплазмоз і для людей. За даними літератури, у світі токсоплазмозом інфіковано не менше 500 млн осіб, що дорівнює загальній кількості інфікованих вірусом гепатиту В. Відповідно до епідеміологічних даних, показник частоти зараження токсоплазмами складає у Європі - 20 - 85\%, у США - 12 - $41 \%$, в інших країнах коливається в межах 50\% [1]. За даними ВО3 щорічно показник хворих в Європейському регіоні сягає понад 2 мільйони чоловік [9].

Питання токсоплазмозу домашніх всеїдних більш актуальне в урбанізованій місцевості, де $\epsilon$ тісний контакт улюбленця та господаря. Оскільки домашні тварини є одним 3 джерел інфікування людини виникає необхідність у системному та більш детальному вивченні ситуації щодо токсоплазмозу домашніх улюбленців. 
Мета роботи. Провести моніторинг поширення токсоплазмозу серед домашніх всеїдних тварин (собаки та коти) та дослідити сезонність прояву захворювання за період з 2014 по 2019 рр.

Матеріали і методи. Матеріалом для досліджень була сироватка крові (761 проба) отримана від котів і собак різних статей, порід та віку, яку отримували в різних клініках ветеринарної медицини м. Одеси. Забір крові проводили 3 ліктьової вени 3 дотриманням правил асептики і антисептики. Виявленні в сироватці крові антитіл щодо токсоплазмозу проводили методом IФА 3 використанням тест системи «Токсоплазма IgG-КС-ИФА» фірми Хема (Росія). Принцип методу визначення антитіл класу $\mathrm{G}$ ( $\mathrm{IgG}$ ) до Toxoplasma gondii базується на використанні «сендвіч»-варіанту твердофазного імуноферментного аналізу.

Виклад основного матеріалу. За період з 2014 по 2019 pp. досліджено 761 проба сироваток крові, з них: 407 проб сироваток крові від котів та 354 проби від собак. В 165 випадках виявили антитіла до збудника токсоплазмозу 87 проб сироваток крові від котів та 78 від собак. У 2014 році досліджено сироваток крові на наявність антитіл до Toxoplasma gondii - 66 проб від котів та 35 від собак. В наступні два роки до ветеринарної клініки надійшло значно більша кількість тварин з підозрою на токсоплазмоз. Так, у 2015 році дослідили 71 пробу сироваток крові від котів та 78 від собак. У 2016 році дослідили найбільше тварин - 143 коти та 123 собаки. Починаючи з 2017 року кількість досліджених котів та собак зменшувалась та становила у 2017 році - 59 досліджених проб сироваток крові від котів та 50 від собак; у 2018 році дослідили 39 проб сироваток крові від котів та 38 від собак та найменший показник зафіксували у 2019 році - 29 і 30 проб сироваток крові відповідно.

Як видно 3 рис. 1, у 2014 році у 28,8 \% пробах сироваток крові котів виявили антитіла до Toxoplasma gondii, аналогічний показник серед собак склав 17,1\%. Найнижчої точки графік сягає у 2015 році. Це відображає, що лише у 9,9\% котів та 14,1\% проб сироваток крові собак виявили антитіла до збудника токсоплазмозу. В 2016 та 2017 роках показник хворих тварин динамічно зріс та досяг серед котів 20,3 \%, а серед собак $19,5 \%$, у 2016 році та $25,4 \%$ і $36,0 \%$ відповідно у 2017 р. У 2018 році показники на графіку знову зменшуються до $17,9 \%$ серед котів та $21,1 \%$ серед собак. У 2019 році було зафіксовано максимальний показник хворих, як серед котів так і серед собак, який склав $34,5 \%$ та 36,7 \% відповідно. 
Agrarian Bulletin of tte Black Sea Littoral. 2020, Issue 97

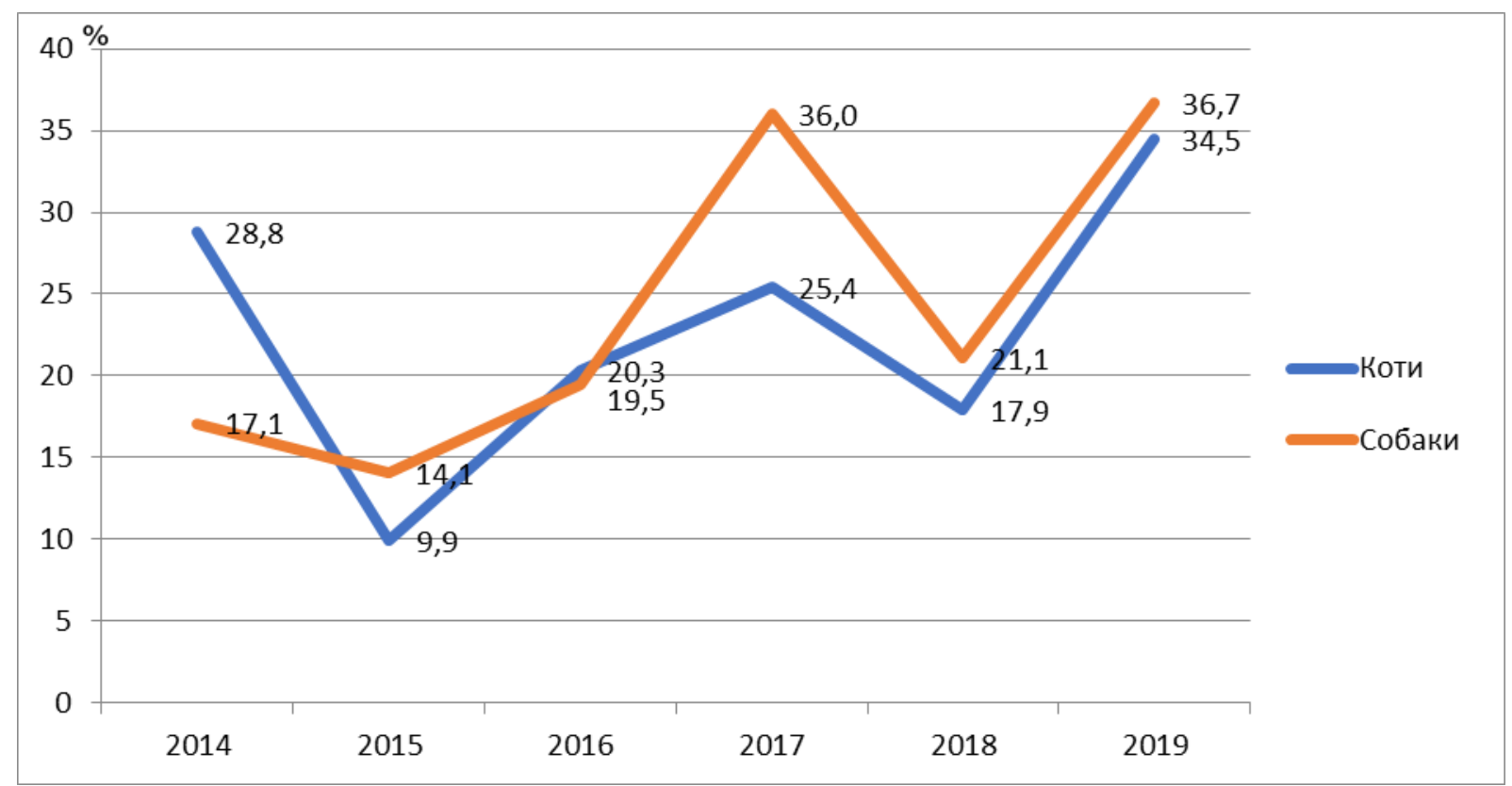

Рис. 1. Динаміка серопозитивних на токсоплазмоз домашніх всеїдних тварин за період 2014-2019 pp.

При аналізі результатів, які отримали при дослідженні сироваток крові домашніх всеїдних тварин відмітили взаємозв'язок між динамікою росту серопозитивних тварин та сезонами року ( рис. 2.)

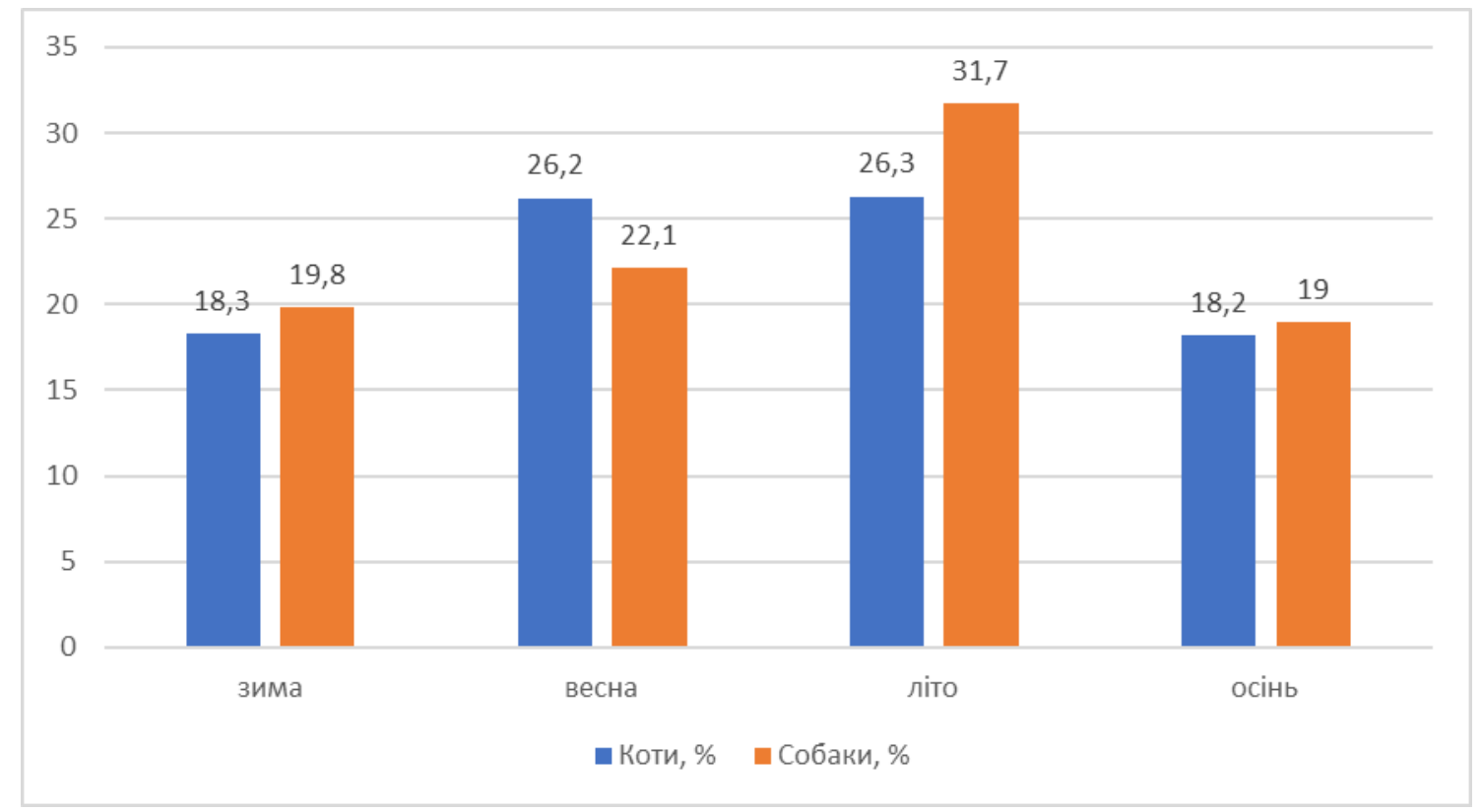

Рис. 2. Виявлення серопозитивних домашніх всеїдних тварин в залежності від сезону року.

Найбільшу кількість серопозитивних домашніх всеїдних тварин зафіксували влітку - 20 проб сироваток крові від котів, що склало 26,3% та від собак 19 проб - 31,7\%. Зменшення позитивно реагуючих тварин відмітили навесні - 17 проб сироваток крові - 26,2\% серед котів та 22 проби - 22,1\% 
серед собак. Взимку кількість інфікованих тварин зменшилась в порівняні 3 весною до 18,3\% (19 проб сироваток крові) серед котів та 19,8\% (20 проб)серед собак. Найнижчий рівень інфікованості серед домашніх всеїдних тварин отримали в зимній період. Серед котів в 19 пробах сироваток крові виявили антитіла, що склало 18,3\% та 20 серед собак - $19 \%$. Отриманні нами дані, щодо сезонного прояву даного захворювання, а саме переважної кількості виявлених хворих влітку збігаються 3 думкою інших авторів $[10,11,12]$.

Провівши аналіз структури захворюваності щодо токсоплазмозу собак та котів за період з 2014 р по 2019 pр. встановили, що антитіла до Toxoplasma gondii виявили в 165 пробах сироваток крові. 3 них: 87 серопозитивних проб сироваток крові отримали від котів, що склало 52,7 \%, та 78 - від собак, що склало 47,3 \% від загальної кількості досліджених тварин (рис. 3).

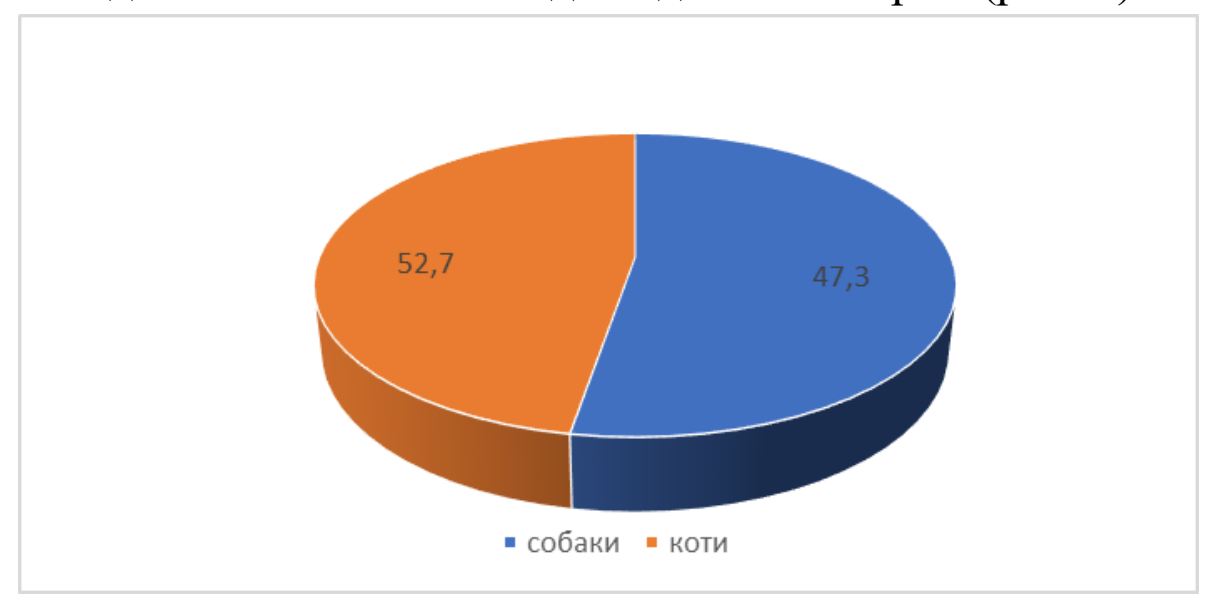

Рис. 3. Відсоткова частка серопозитивних котів та собак від загальної кількості досліджених всеїдних тварин.

Найвищий відсоток серопозитивних котів зафіксували у 2014 р - 76,0 \% від загальної кількості досліджених тварин. Найнижчий відсоток у 2015 році $38,9 \%$. Серед собак навпаки у 2015 році відсотковий рівень позитивних сироваток крові був найвищим - 61,1 \%, а у 2014 році найнижчим - 24,0\%.

Домінування прояву токсоплазмозу у котів порівняно 3 собаками описано в літературі [6]. Це стосується домашніх всеїдних тварин. В той час, як серед безпритульних тварин спостерігали навпаки вищий рівень захворюваності серед собак [8].

Висновки. 1. Виявлено, що 21,7\% досліджених проб сироваток крові домашніх всеїдних тварин мали антитіла до Toxoplasma gondii. Встановлено залежність між сезонами року та кількістю серопозитивних щодо токсоплазмозу тварин. Найвищий показник серопозитивності, як серед котів так і серед собак фіксували влітку - 26,3\% та $31,7 \%$ відповідно. Найнижчий показник серопозитивності, як серед котів так і серед собак фіксували восени 18,2\% та 19,0 \% відповідно. Встановлено, що відсотковий вміст хворих котів та 
собак, в загальної структурі захворюваності становив серед 52,7 \% та 47,3\% відповідно.

Перспективи подальших досліджень. Враховуючи широке поширення токсоплазменної інвазії серед домашніх всеїдних тварин, подальші дослідження будуть скеровані на дослідження сільськогосподарських тварин.

\section{ЛIТЕРАТУРА}

1. Алексанян T.I., Задорожний А.М., Зінчук О.М., Зубач О. О., Орфін А. Я., Чудіна Ю. А. Токсоплазмоз головного мозку в імунокомпетентних осіб. Львівський національний медичний університет ім. Данила Галицького. URL:file://C:/Users/Admin/Downloads/4734-Текст\%20статті-17691-2-1020150705.pdf

2. Катков С. С. Токсоплазмоз домашних плотоядных в условиях Воронежской области. Диссертация на соискание ученой степени кандидата ветеринарных наук. Воронеж, 2017.

3. Лазаренко, О. Л. Соловйова Л. М. Діагностика токсоплазмозу котів. Матеріали міжнародної науково - практичної конференції магістрантів. Актуальні проблеми ветеринрної медицини. Біла Церква, 2018. С. 57-59.

4. Прудкий, Ю.В., Галат М. В. Токсоплазмоз - поширена хвороба тварин. Ветеринарна медицина України. 2015. № 2 . С 23-24.

5. Calero-Bernal Rafael, Gennari Solange M. Clinical Toxoplasmosis in Dogs and Cats: An Update. Front Vet Sci. Feb 26. 2019.

6. Center for Disease Control and Prevention. Taxoplasmosis (Toxoplasma infection), 2018. URL:https://www.cdc.gov/parasites/toxoplasmosis/biology.html

7. Ibtissem Lahmar, Arwa Lachkhem, Oussama Babba, Darine Slama, Aida Trabelsi, Karine Passebosc-Faure, Marie Laure Dardé \& Hamouda Babba. First isolation and molecular characterization of Toxoplasma gondii strains from human congenital toxoplasmosis cases in Monastir. 2020 URL: https://www.nature.com/articles/s41598-020-59060-w

8. Meireles L. R., Galisteo A. J., Pompeu E., Andrade H. F. Toxoplasma gondii spreading in an urban area evaluated by seroprevalence in free-living cats and dogs Tropical Medicine and International Health. Vol. 9. 2004. P. 879.

9. World Health Organization. Regional office for Europe. Toxoplasmosis. 2016.

URL:https://www.euro.who.int/ru/health-topics/Lifestages/pages/news/news/2016/11/toxoplasmosis-greater-awareness-needed

10. Scharesa G., Zillera M., Herrmanna D. C.,Globokarb M. V., Pantchev N., Conrathsa F. J. Seasonality in the proportions of domestic cats shedding Toxoplasma gondii or Hammondia hammondi oocysts is associated with climatic factors. International Journal for Parasitology. Vol. 46, Issue 4. April 2016. Pages 263-273. URL: https://www.sciencedirect.com/science/article/abs/pii/S0020751916000072 
11. Schares Gereon, Ziller M., Herrmann D.C. Seasonality in the proportions of domestic cats shedding Toxoplasma gondii or Hammondia hammondi oocysts is associated with climatic factors. International journal for parasitology 46(4) January 2016. URL: https://www.researchgate.net/publication/

12. Stelzera S., Bassob W., Benavides_Silvánc J., Ortega-Morad L.M., Maksimova P., Gethmanna J., Conrathsa F.J., Scharesa G. Toxoplasma gondii infection and toxoplasmosis in farm animals: Risk factors and economic impact. Food and Waterborne Parasitology. Vol. 15, June 2019. URL: https://www.sciencedirect.com/science/article/pii/S2405676618300441

\section{СЕРОЛОГИЧЕСКИЙ МОНИТОРИНГ РАСПРОСТРАНЕНИЯ ТОКСОПЛАЗМОЗА СРЕДИ ДОМАШНИХ ВСЕЯДНЫХ ЖИВОТНЫХ В ГОРОДЕ ОДЕССА \\ В. Кустуров}

В статье приведень результаты исследований на токсоплазмоз сывороток крови кошек и собак. Утановлено, что из 761 проб сывороток крови животных в 21,7\% обнаружили антитела к Toxoplasma gondii. Обнаружили сезонную закономерность роста серопозитивных животных летом $u$ снижение их количества осенью. Содержание серопозитивных кошек и собак в видовой структуре заболевания почти одинаковое и составляет - 52,7\% и 47,3\% соответственно.

Ключевые слова: токсоплазмоз, кошки, собаки, серологический мониторинг, антитела, Toxoplasma gondii.

\section{SEROLOGICAL MONITORING DISTRIBUTION TOXOPLASMOSIS AMONG HOME ANIMALS IN THE CITY OF ODESSA}

\section{Kusturov}

The article presents the results of studies on toxoplasmosis of the sera of cats and dogs. It was found that of 761 samples of domestic serum in 21,7\% found antibodies to Toxoplasma gondii. Also found a seasonal pattern of growth of seropositive animals in summer and a decrease in autumn. It was investigated that the percentage of seropositive cats and dogs in the species structure of the disease was almost the same and was $-52,7 \%$ and $47,3 \%$, respectively.

Key words: toxoplasmosis, cats, dogs, serological monitoring, antibodies, Toxoplasma gondii. 